\title{
Desiccation sensitivity from different coffee seed phenological stages ${ }^{1}$
}

\author{
Flávia Carvalho Santos ${ }^{2}$, Sttela Dellyzete Veiga Franco da Rosa ${ }^{3 *}$, Édila Vilela de \\ Rezende Von Pinho ${ }^{2}$, Marcelo Angelo Cirillo ${ }^{4}$, Aline da Consolação Sampaio Clemente ${ }^{2}$
}

\begin{abstract}
Maturity stage and drying method are the factors that most influence coffee seed quality. The objective of this study was to assess the physiological quality and investigate the electrophoretic patterns of catalase and endo- $\beta$-mannanase enzymes and heat resistant proteins in coffee seeds harvested at different phenological stages and dried under different conditions. Physiological quality was assessed when the seeds had developed the green, greenish-yellow, cherry, overripe and dry stages after three treatments: no drying, conventional drying and fast drying. After each treatment, the physiological quality of the seeds was assessed using the germination test and electrophoretic patterns of heat resistant proteins and the activity of catalase and endo- $ß$-mannanase enzymes. Seeds harvested at the cherry phenological stage had the best physiological quality, and the drying process reduced quality at the cherry, overripe and dry stages. This reduction was greater under the faster drying process, but at the greenish-yellow stage, seeds had better physiological quality after slow drying. Regarding the results from electrophoretic analysis, endo- $\beta$-mannanase and catalase activities increase as the ripeness stages advance; the activity of endo-ß-mannanase is directly associated with the deterioration process; the expression of heat resistant proteins increases with maturation process and is associated with seed physiological quality.
\end{abstract}

Index terms: Coffea arabica L., seed drying, physiological quality, protein profile.

\section{Sensibilidade à dessecação de sementes de café em diferentes estádios fenológicos}

\begin{abstract}
RESUMO - O estádio de maturação e a secagem são os fatores que mais influenciam a qualidade de sementes de café. O objetivo foi avaliar a qualidade fisiológica e investigar os padrões eletroforéticos das enzimas catalase, endo- $\beta$-mananase e das proteínas resistentes ao calor em sementes de café, em diferentes estádios e secadas em diferentes condições. Avaliouse a qualidade nos estádios verde, verde cana, cereja, passa e seco, após tratamentos de secagem: sem secagem, secagem convencional e secagem rápida. A qualidade fisiológica foi avaliada pelo teste de germinação, padrão eletroforético das proteínas resistentes ao calor e atividade das enzimas catalase e endo- $\beta$-mannanase. Sementes colhidas no estádio cereja apresentam melhor qualidade fisiológica e a secagem reduz a qualidade das sementes colhidas nos estádios de maturação cereja, passa e seco. Esta redução foi maior após secagem mais rápida, mas no estádio verde cana as sementes apresentam melhor desempenho fisiológico após secagem lenta. Com relação às análises eletroforéticas, a atividade das enzimas endo-ßmannanase e catalase aumenta quando o processo de maturação avança; a atividade da endo-ß-mannanase está diretamente relacionada com o processo de deterioração; a expressão de proteínas resistentes ao calor aumenta com a maturação e está associada à qualidade fisiológica das sementes de café.
\end{abstract}

Termos para indexação: Coffea arabica L., secagem, qualidade fisiológica, perfil proteico.

\section{Introduction}

The phenological cycle of coffee trees consists of vegetative and reproductive stages. In the vegetative stages, branches are formed with buds at the nodes during long days. When the days are shortened, vegetative buds are

\footnotetext{
${ }^{1}$ Submitted on $05 / 31 / 2013$. Accepted for publication on 12/10/2013. ${ }^{2}$ Departamento de Agricultura, Universidade Federal de Lavras, UFLA, Caixa Postal 3037, 37200 - Lavras, MG, Brasil.

${ }^{3}$ Embrapa Café, Caixa Postal 40315, 70770-901 - Brasília, DF, Brasil.
}

photoperiodically induced to differentiate reproductive buds (Pezzopane et al., 2003).

Reproductive stages were described by Pezzopane et al. (2003) using a phenological scale of Coffea arabica L. ranging from 0 to 11 as follows: dormant floral bud (0); wet floral bud (1); floral bud (2); flowering (3); post-flowering

${ }^{4}$ Departamento de Agricultura, Universidade Federal de Lavras,UFLA, Caixa Postal 3037, 37200 - Lavras, MG, Brasil.

*Corresponding author <sttela.rosa@embrapa.br> 
or petal fall off (4); primordial fruits, starting the growth after fertilization (5); expanding fruits (6); green fruits with endosperms (7); greenish-yellow fruits starting the ripening, without color change (8); fully ripe fruit (9); overripe fruit, starting to decay (10); and the dry fruit (11).

The reproductive stages are characterized by several blooms when a principal one is followed by others in numbers that vary from year to year because of weather conditions, genetic variability and crop management. These responses of the coffee tree contribute to uneven ripening, which also occurs within the same blooming period (Pezzopane et al., 2005). Non-uniform ripening causes harvest problems that damage seed quality of the lot, resulting in nonuniform germination and low seed vigor.

For commercial coffee seed production, cherries are typically collected at physiological maturity and drying is one of the most important post-harvest steps. Drying can be defined as the process of energy and mass exchange from the tissues to the drying air, so that a determined quantity of water is removed by evaporation. This phenomenon is affected by various factors such as drying temperature, relative humidity and drying air velocity. Controlling these factors is essential to obtain high quality coffee seeds.

Orthodox seeds from angiosperms acquire tolerance to desiccation at the end of ripening, when their water content is reduced and the embryo enters a state of metabolic quiescence and survives in this state for a period that varies with the species (Marcos-Filho, 2005; Rosa et al., 2005). Desiccation tolerance in seeds seems to be mediated by protective systems that prevent lethal damage to the different cell components, including membranes, proteins and cytoplasm. Several physiological alterations can occur in seeds during desiccation including changes in the relative composition of membrane phospholipids, accumulation of reducing carbohydrates such as sucrose and oligosaccharides, lea (late embryogenesis accumulated) protein synthesis and the ability to prevent, tolerate or repair free radical attacks (Leprince et al., 1993, Rosa et al., 2000; Berjak, 2006). Although the function of the lea proteins has not yet been fully investigated, reports have suggested their importance for seeds acquiring tolerance to desiccation because of their stability, affinity with water molecules and abundance in desiccationtolerant organisms (Wolkers et al, 1998).

Specific seeds of several species become tolerant to desiccation at certain stages of development, after a phase of intolerance. The results from coffee seeds vary by species in Coffea. Ellis et al. (1991) observed that C. arabica seeds obtained from fruits at the intermediate ripeness stage (greenish-yellow) were more tolerant to desiccation than those harvested at the cherry (ripe fruit) or at the green stage (unripe). Guimarães et al. (2002) observed that seeds from cherry and greenish-yellow fruit germinated better than those from green fruit. Thus, it has been reported that coffee seeds acquire maximum germination capacity when the fruits are between the greenish-yellow and cherry stages, and these results suggest that completely mature seeds of species sensitive to desiccation may not possess maximum vigor because the germination process may start at the end of the maturation process.

When the germination is limited by the endosperm, as in Coffea arabica L. seeds, the endosperm needs to be softened in order for the root to protrude. This is accomplished by enzymes, including endo- $\beta$-mannanase, found in the endosperm under different isoforms, and two of these are inhibited by abscisic acid during the endosperm weakening in the region close to the root, reducing root pressure force (Silva et al., 2004).

The objective of this study was to assess the physiological quality and investigate the electrophoretic patterns of the catalase and endo- $\beta$-mannanase enzymes and the heatresistant proteins of coffee seeds at different phenological stages and dried under different conditions.

\section{Materials and Methods}

Coffea arabica $\mathrm{L}$. fruits of the cultivar Rubi were collected in a plantation on the campus of Universidade Federal de Lavras, at the green, greenish-yellow, cherry, overripe and dry stages. Each stage was obtained at different times when the plants had most of the fruit at the same phenological stage. In randomly chosen plants, the fruits were collected from the middle branches and in the middle of the branches. After harvesting, fruits at each phenological stage were collected to standardize the ripeness stage following the phenological scale described by Pezzopane et al. (2003).

Seeds were dried without removing the fruit structures to avoid mechanical damage and standardize the materials during drying. After rapid sun drying to remove excess surface water, the fruits were submitted to the following drying treatments: 1) slow drying under shade (conventional slow drying method), where the fruits were dried in a single layer using plastic trays under temperature and relative humidity environment conditions until the desired moisture content; 2) controlled fast drying using a forced-air circulation oven (Nova Etica, 420-3D) set for a constant $35^{\circ} \mathrm{C}$, and 3) no drying treatment, whereby seeds were assessed immediately after harvesting. The decrease in water content was followed by weighing during the drying process in both methods to reach about $12 \%$ moisture content (Ellis et al., 1991) determined by the chamber method (Brasil, 2009). 
After drying, the fruits were manually hulled and the seeds without parchment were assessed by the standard germination test with four replications of 50 seeds for each treatment. The seeds were sown on germination paper, moistened with water equivalent to two and a half times the weight of the dry substrate and germinated at $30{ }^{\circ} \mathrm{C}$, in the presence of light (750 to 1.250 lux). They were counted and evaluated at 15 and 30 days after sowing (Brasil, 2009) and the results were reported in percentage. Fifteen days after sowing, the percentage of protruded roots was assessed. Radicle protrusion was considered as the visual identification of the white embryonic axis and corresponds to the sensu stricto germination. To be considered normal seedlings, they had to present a differentiated main root with at least two secondary roots. Thirty days after sowing, the percentage of normal and strong normal seedlings was counted. A strong normal seedling had developed a root longer than $2.5 \mathrm{~cm}$ and had at least two secondary roots. Forty-five days after sowing, seedlings with differentiated cotyledonary leaves were counted and the results were reported in percentage.

Protein expression by electrophoretic analysis: Fifty seeds from each treatment were ground using a Tecnal TE613/1 grinder, refrigerated at $4{ }^{\circ} \mathrm{C}$ in the presence of PVP, and stored at $-86^{\circ} \mathrm{C}$ for later electrophoretic analysis of the heat resistant enzymes, endo-ß-mannanase and catalase. Heat resistant proteins were analyzed using the methodology described by Alfenas (1998). The following methodologies were used for electrophoretic analysis.

To extract endo- $\beta$-mannanase enzymes, $200 \mathrm{mg}$ of ground seed were weighed and $600 \mu \mathrm{L}$ extraction buffer $(0.1 \mathrm{M}$ Hepes $/ 0.5 \mathrm{M} \mathrm{NaCl}$ and ascorbic acid (5 mg ascorbic acid per $\mathrm{mL}$ buffer), $8.0 \mathrm{pH}$ ) were added. The samples were centrifuged for $30 \mathrm{~min}$ at 10,000 $\mathrm{g}$ and $2 \mu \mathrm{L}$ of the supernatant were applied in a polyacrylamide gel containing $6 \mathrm{~mL} \mathrm{LBG}$ (Locust Bean Gum), $0.24 \mathrm{~g}$ agarose and $24 \mathrm{~mL}$ buffer, $\mathrm{pH} 5.0$ (1M citric acid/ $0.4 \mathrm{M} \mathrm{Na}_{2} \mathrm{HPO}_{4} 2 \mathrm{H}_{2} \mathrm{O}$ ). Aliquots were applied in $2 \mathrm{~mm}$ holes drilled in the gel. This gel was incubated for $21 \mathrm{~h}$ following the methodology reported by Silva et al. (2004). Endo-ß-mannanase enzyme activity was calculated based on Downie et al. (1994).

To extract the catalase enzyme, $280 \mu \mathrm{L}$ extraction buffer $(0.2 \mathrm{M}$ Tris, $8.9 \mathrm{pH})$ were added to $100 \mathrm{mg}$ seed powder, homogenized in vortex and stored for one hour at $4{ }^{\circ} \mathrm{C}$. The samples were centrifuged at $14,000 \mathrm{rpm}$ and $4{ }^{\circ} \mathrm{C}$ for $15 \mathrm{~min}$ and $60 \mu \mathrm{L}$ of the supernatant were applied to the polyacrylamide gels. The tris glycerin gel/electrode buffer system was used and electrophoresis was carried out at $150 \mathrm{~V}$ for four $\mathrm{h}$. The gels were developed and the results were photographed using a Sony 12.1 megapixel digital camera with a $38 \mathrm{~mm}$ lens.

SDS-PAGE method and extraction procedures recommended by Blackman et al. (1991) were used for heat resistant proteins analyses. Samples of $100 \mathrm{mg}$ of embryonic axes were macerated in $1 \mathrm{~mL}$ of extraction buffer $(50 \mathrm{mM}$ Tris- $\mathrm{HCl} \mathrm{pH} 7.5,500 \mathrm{mM} \mathrm{NaCl}, 5 \mathrm{mM} \mathrm{MgCl}_{2}, 1 \mathrm{mM}$ PMSF), and the samples were centrifuged at $16,000 \mathrm{xG}$ for 30 minutes at $4{ }^{\circ} \mathrm{C}$. The supernatant was incubated in a water bath at $85{ }^{\circ} \mathrm{C}$ for 15 minutes and centrifuged again as before. The supernatant was transferred to a new tube and the pellet was discarded, before application on gel. 40 $\mathrm{mL}$ of sample buffer $(2.5 \mathrm{~mL}$ glycerol, $0.46 \mathrm{~g}$ SDS, $20 \mathrm{mg}$ bromophenol blue, Tris- $\mathrm{HCl} \mathrm{pH} 7.5$ ) were added to $70 \mathrm{~mL}$ of each extract, followed by incubation in a water bath with boiling water for five minutes. Then, $50 \mathrm{~mL}$ were applied to each sample of polyacrylamide gel $(12.5 \%$ separating and $6 \%$ concentrator gel). Tris-glycine SDS+, $8.9 \mathrm{pH}$ was the running buffer used, and the electrophoretic run was performed in the vertical system at room temperature and constant voltage of $150 \mathrm{~V}$ for four hours. After running, the gels were stained in 0.05\% Coomassie Brilliant Blue solution for 24 hours and discoloured in 5\% ethanol and $10 \%$ acetic acid and $85 \%$ water solution, according to Alfenas (1998). Evaluation of the gels was performed on a transilluminator, taking band intensity variation into account.

A complete randomized design was used, in a $5 \times 3$ factorial design consisting of five cherry ripeness stages (green, greenish-yellow, cherry, overripe and dry) and three drying methods (drying under controlled environment, conventional drying and no drying) with four replications of the resulting treatments from the combination of the factors to obtain sixty plots. The data were submitted to analysis of variance and the means were compared by the Scott-Knott test at $5 \%$ probability.

\section{Results and Discussion}

Analysis of variance showed a significant effect of the interaction between the phenological stages and drying treatments for all the variables analyzed, except for percentage of normal seedlings counted on day 15, which indicates that the effects of the drying treatments depended on the phenological stage. Seeds collected at the ripe (cherry) and overripe stages and those not artificially dried had a higher percentage of radicle protrusion than those dried under shade or in a forced-air circulation oven (Table 1). When dried under shade, the seeds from greenish-yellow and cherry fruit stages had the highest radicle protrusion values, but they did not differ statistically among themselves. Controlled drying was the drying method that had the lowest results for all stages while the cherry stage had the highest protrusion percentage. 
It was further observed that drying green stage fruits did not influence the physiological quality of the seeds as measured by root protrusion.

The percentage of normal seedlings at 30 days (Table 2) was higher in seeds collected at the cherry stage and the lowest results were observed in seeds harvested at the green and overripe stages. The drying process affected germination in seeds from all phenological development stages. Guimarães et al. (2002) also observed higher germination percentages in seeds prior to drying at all stages studied.

Table 1. Mean percentage of coffee seed root protrusion obtained from fruits collected at different development stages and submitted to different drying treatments ${ }^{(1)}$.

\begin{tabular}{cccc}
\hline \multirow{2}{*}{ Stages } & \multicolumn{3}{c}{ Root protusion (\%) } \\
\cline { 2 - 4 } & $\begin{array}{c}\text { Without } \\
\text { drying }\end{array}$ & $\begin{array}{c}\text { Conventional } \\
\text { slow drying }\end{array}$ & $\begin{array}{c}\text { Controlled } \\
\text { fast drying }\end{array}$ \\
\hline Green & $1.00 \mathrm{Da}$ & $1.67 \mathrm{Ca}$ & $0.67 \mathrm{Ea}$ \\
Greenish-yellow & $44.00 \mathrm{Cb}$ & $77.34 \mathrm{Aa}$ & $74.67 \mathrm{Ba}$ \\
Cherry & $89.00 \mathrm{Aa}$ & $81.00 \mathrm{Ab}$ & $79.67 \mathrm{Ab}$ \\
Overripe & $89.67 \mathrm{Aa}$ & $61.67 \mathrm{Bc}$ & $68.00 \mathrm{Cb}$ \\
Dry & $66.34 \mathrm{Ba}$ & $60.00 \mathrm{Bb}$ & $46.00 \mathrm{Dc}$ \\
\hline
\end{tabular}

${ }^{(1)}$ Means followed by the same uppercase letter in the column and lowercase letter on the line do not differ significantly at the level of $5 \%$ by the Scott Knott test.

Table 2. Percentage of normal seedlings derived from coffee seeds harvested at different stages of development and submitted to different drying treatments ${ }^{(1)}$.

\begin{tabular}{cccc}
\hline \multirow{2}{*}{$\begin{array}{c}\text { Development } \\
\text { Stages }\end{array}$} & $\begin{array}{c}\text { Without } \\
\text { drying }\end{array}$ & $\begin{array}{c}\text { Conventional } \\
\text { slow drying }\end{array}$ & $\begin{array}{c}\text { Controlled } \\
\text { fast drying }\end{array}$ \\
\cline { 2 - 4 } Green & $1.00 \mathrm{Ea}$ & $1.67 \mathrm{Da}$ & $0.00 \mathrm{Da}$ \\
Greenish-yellow & $76.00 \mathrm{Ca}$ & $73.67 \mathrm{Aa}$ & $62.34 \mathrm{Bb}$ \\
Cherry & $90.67 \mathrm{Aa}$ & $75.33 \mathrm{Ab}$ & $68.33 \mathrm{Ac}$ \\
Overripe & $82.67 \mathrm{Ba}$ & $66.00 \mathrm{Bb}$ & $60.00 \mathrm{Bc}$ \\
Dry & $52.00 \mathrm{Da}$ & $23.33 \mathrm{Cb}$ & $26.00 \mathrm{Cb}$ \\
\hline
\end{tabular}

${ }^{(1)}$ Means followed by the same uppercase letter in the column and lowercase letter on the line do not differ significantly at the level of $5 \%$ by the Scott Knott test.

Higher values were observed in the strong normal seedling percentage results at 30 days (Table 3 ) in seeds collected at the cherry stage without drying. After drying under shade, however, the physiological quality of the seeds collected at the cherry stage was the same as seeds from greenish-yellow fruits, which were favored by the slow drying process. These improved results for seeds from greenish-yellow fruits after drying under shade were also observed in the root protrusion results, which suggested enhanced physiological quality of seeds as they lose water more slowly. Drying under shade and drying in an oven reduced physiological quality in all the phenological stages, except for the greenish-yellow fruits, where drying under shade produced better percentage of normal seedlings than the treatment without drying (Table 3). Rosa et al. $(2007,2011)$ also showed that coffee seeds from greenish-yellow fruits had similar physiological performance to seeds collected at the cherry stage.

Table 3. Mean percentage of normal strong seedlings derived from coffee seeds harvested at different development stages and submitted to different drying treatments ${ }^{(1)}$.

\begin{tabular}{cccc}
\hline \multirow{2}{*}{$\begin{array}{c}\text { Development } \\
\text { Stages }\end{array}$} & \multicolumn{3}{c}{ Strong normal seedlings (\%) } \\
\cline { 2 - 4 } & Without & $\begin{array}{c}\text { Conventional } \\
\text { slow drying }\end{array}$ & $\begin{array}{c}\text { Controlled } \\
\text { fast drying }\end{array}$ \\
\hline Green & $1.00 \mathrm{Ea}$ & $1.34 \mathrm{Da}$ & $0.00 \mathrm{Da}$ \\
Greenish-yellow & $63.33 \mathrm{Cb}$ & $66.67 \mathrm{Aa}$ & $50.34 \mathrm{Bc}$ \\
Cherry & $88.00 \mathrm{Aa}$ & $68.67 \mathrm{Ab}$ & $57.00 \mathrm{Ac}$ \\
Overripe & $69.33 \mathrm{Ba}$ & $54.67 \mathrm{Bb}$ & $50.67 \mathrm{Bc}$ \\
Dry & $10.34 \mathrm{Da}$ & $10.00 \mathrm{Ca}$ & $12.00 \mathrm{Ca}$ \\
\hline
\end{tabular}

(1) Means followed by the same uppercase letter in the column and lowercase letter on the line do not differ significantly at the level of $5 \%$ by the Scott Knott test.

Analysis of the percentage results of normal strong seedlings (Table 3) showed similar trends to that of the normal seedling percentage for both the phenological stages and the drying treatments. Only the greenish-yellow stage dried under shade improved seed quality, unlike the other stages, where both drying under shade and drying in an oven reduced seed quality. This may be attributed to continued ripening of the greenish-yellow fruits after harvest, main when they were slower dryed. Pereira et al. (2005) reported ethylene production during coffee fruit ripening, and expression of genes of the ACC oxidase enzyme (acid 1-carboxylic-1-aminocyclopropane) during ripening in different organs of the plant as well as increased ethylene production in greenish-yellow fruits after endosperm formation that decreased at the cherry stage, indicating a climacteric phase during coffee fruit ripening.

Analysis of the effects of drying on seed vigor assessed by the percentage of expanded cotyledon leaves at 45 days (Table 4) showed that the coffee seedlings achieved the highest percentage of cotyledon leaves at the cherry stage after drying under shade, and drying in an oven resulted in greater reductions in seed quality. These results emphasize the importance of further studies to improve the drying process for coffee seeds, which is essential to obtain vigorous seedlings. 
Table 4. Percentage of plants with expanded cotyledon leaves derived from coffee seeds harvested at different development stages and submitted to different drying treatments ${ }^{(1)}$.

\begin{tabular}{cccc}
\hline \multirow{2}{*}{$\begin{array}{c}\text { Development } \\
\text { Stages }\end{array}$} & $\begin{array}{c}\text { Without } \\
\text { drying }\end{array}$ & $\begin{array}{c}\text { Conventional } \\
\text { slow drying }\end{array}$ & $\begin{array}{c}\text { Controlled } \\
\text { fast drying }\end{array}$ \\
\hline Green & $0.00 \mathrm{Ea}$ & $0.00 \mathrm{Ea}$ & $0.00 \mathrm{Ea}$ \\
Greenish-yellow & $42.33 \mathrm{Bb}$ & $57.34 \mathrm{Ba}$ & $27.00 \mathrm{Bc}$ \\
Cherry & $58.34 \mathrm{Ab}$ & $66.67 \mathrm{Aa}$ & $37.67 \mathrm{Ac}$ \\
Overripe & $32.33 \mathrm{Cb}$ & $43.67 \mathrm{Ca}$ & $21.00 \mathrm{Cc}$ \\
Dry & $11.34 \mathrm{Da}$ & $12.00 \mathrm{Da}$ & $11.67 \mathrm{Da}$ \\
\hline
\end{tabular}

${ }^{(1)}$ Means followed by the same uppercase letter in the column and lowercase letter on the line do not differ significantly at the level of $5 \%$ by the Scott Knott test.

In several studies, slower drying of coffee seeds obtained during drying under shade has resulted in superior physiological quality and, therefore, it is commonly recommended for seed production (Brandão Junior et al., 2002; Veiga et al., 2007; Vieira et al., 2007).

Seeds from the green and dry phenological stages had the lowest physiological responses, before and after drying. Most of the seeds from green fruits completed the first phase of the tri-phasic germination pattern, that is, imbibition. However, these seeds did not initiate root protrusion and remained wet, intact and without any signs of deterioration until the end of the germination test. This finding may be attributed to the fact that the seeds were unripe and had not reached physiological maturity. These seeds were not dead.

For a better understanding of the results, the electrophoretic profiles of the heat resistant proteins catalase and endo- $\beta$ mannanase were determined. Figure 1 shows the expression of heat resistant proteins with absence of band and also lower band intensity in the treatments without drying and at the initial fruit development, green and greenish-yellow stages. The expression of heat resistant proteins is considered an important factor associated with protection mechanisms against damage caused by water removal from plant tissues. These proteins are accumulated during the later stages, either before or during drying (Taiz and Zeiger, 2004) and they are present in seeds and organisms tolerant to desiccation. This explains the lower band intensity, the absence at the earlier ripeness stages, the greater band intensity at the more advanced ripeness stages or after drying seeds from unripe fruits.

No significant differences were observed in the endoß-mannanase enzyme activity (Table 5) at the different phenological stages, but seeds harvested at the overripe stage tended to have greater activity although this was not statistically significant. Drying did not affect enzyme activity in seeds collected at the green, greenish-yellow and cherry stages. Greater activity was observed in the endo-ß-mannanase enzyme in seeds collected at the dry stage and submitted to drying under shade. Coffee seed germination is limited by the endosperm that has to be softened in the micropilar or endosperm cap region so that the root can emerge. This softening process is performed by several enzymes, mainly endo- $\beta$-mannanase, present in the endosperm of coffee seeds where their activities start in the region close to the root during germination. Marraccini et al. (2001), using the Northernblot technique, identified that the gene that codifies endo- $\beta$ mannanase is expressed during seed germination.

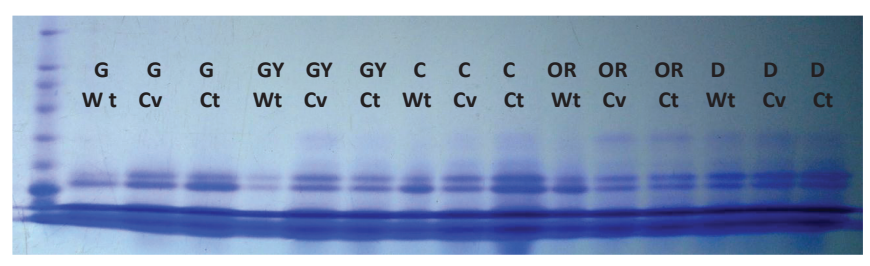

Figure 1. Activity of heat resistant proteins in coffee seeds harvested at the green $(\mathrm{G})$, greenish-yellow (GY), cherry (C), overripe (OR) and dry (D) development stages, submitted to conventional slow drying $(\mathrm{Cv})$, controlled fast drying $(\mathrm{Ct})$ and without drying $(\mathrm{Wt})$.

Table 5. Activity of the endo- $\beta$-mananase enzyme in coffee seeds harvested at the green, greenish-yellow, cherry, overripe and dry development stages, submitted to conventional slow drying, controlled fast drying and without drying ${ }^{(1)}$.

\begin{tabular}{cccr}
\hline \multirow{2}{*}{$\begin{array}{c}\text { Development } \\
\text { Stages }\end{array}$} & \multicolumn{3}{c}{$\begin{array}{c}\text { Activity of the endo- } \beta \text {-mananase } \\
\text { (pmol/min/g) }\end{array}$} \\
\cline { 2 - 4 } & $\begin{array}{c}\text { Without } \\
\text { drying }\end{array}$ & $\begin{array}{c}\text { Conventional } \\
\text { slow drying }\end{array}$ & $\begin{array}{r}\text { Controlled } \\
\text { fast drying }\end{array}$ \\
\hline Green & $0.950 \mathrm{Aa}$ & $1.990 \mathrm{Ca}$ & $0.200 \mathrm{Ba}$ \\
Greenish-yellow & $0.930 \mathrm{Aa}$ & $0.600 \mathrm{Ca}$ & $0.790 \mathrm{Ba}$ \\
Cherry & $1.010 \mathrm{Aa}$ & $6.720 \mathrm{Ca}$ & $0.840 \mathrm{Ba}$ \\
Overripe & $2.800 \mathrm{Ab}$ & $39.800 \mathrm{Ba}$ & $0.0690 \mathrm{Bb}$ \\
Dry & $0.970 \mathrm{Ac}$ & $352.330 \mathrm{Aa}$ & $37.460 \mathrm{Ab}$ \\
\hline
\end{tabular}

(1) Means followed by the same uppercase letter in the column and lowercase letter on the line do not differ significantly at the level of $5 \%$ by the Scott Knott test.

Although the activity of this enzyme is related to coffee seed germination, it is also associated with deterioration. Since endo- $\beta$-mannanase acts on the cell wall, its activity is intense during the deterioration process. This can be clearly observed in the results in the present study for seeds collected at the dry stage and submitted to drying. These seeds showed 
higher percentage of radical protrusion, but fewer normal seedlings.

Figure 2 shows the electrophoretic profile of the catalase enzymes, where less enzymatic activity can be observed in seeds not submitted to drying and in coffee seeds collected at the green stage. Recent studies have reported that loss of seed viability during drying is accompanied by increases in oxygen reactive species (EROS) because of physiological stress. However, there are mechanisms in plants and seeds to prevent EROS formation, including enzymes such as catalase (Fagagna, 2008; Takahashi et al., 2007), which removes hydrogen peroxide, an extremely toxic compound to seeds.

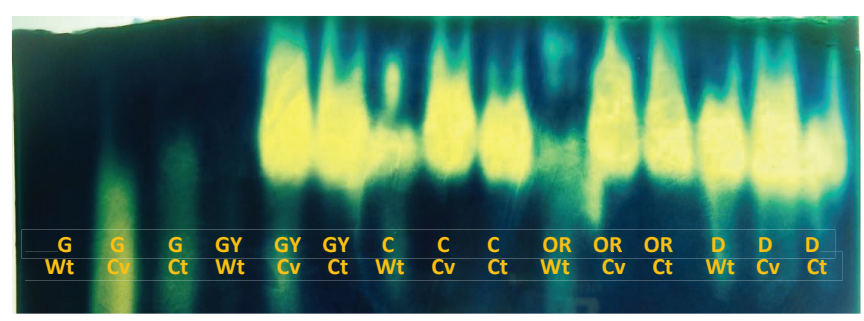

Figure 2. Catalase enzyme activity in coffee seeds harvested at the green $(\mathrm{G})$, greenish-yellow (GY), cherry $(\mathrm{C})$, overripe (OR) and dry (D) development stages, submitted to conventional slow drying $(\mathrm{Cv})$, controlled fast drying $(\mathrm{Ct})$ and without drying $(\mathrm{Wt})$.

Catalase enzyme was not observed in seeds collected at the early green stage, but this enzyme was expressed as the ripeness stages advanced. The drying process, whether conventional or controlled, resulted in increased catalase expression, showing an increase of this enzyme activity when the seeds were stressed.

\section{Conclusions}

Coffea arabica L. seeds, cv Rubi, harvested at the cherry phenological stage, have the highest physiological quality.

The drying process reduces coffee seed physiological quality when harvested at the cherry, overripe and dry maturation stages, and this reduction is greater in the faster drying process.

Greenish-yellow stage coffee seeds have enhanced physiological performance after slow drying.

Endo-ß-mannanase and catalase enzyme activities increase as the ripeness stages advance. The activity of endoß-mannanase enzyme is directly associated with coffee seed deterioration process.

The expression of heat resistant proteins increases with maturation process and it is associated with coffee seed physiological quality.

\section{Acknowledgement}

To Coordenação de Aperfeiçoamento de Pessoal de Nível Superior - CAPES for financial support granted to this study.

\section{References}

ALFENAS, A.C. (Ed.). Eletroforese de isoenzimas e proteinas afins: fundamentos e aplicações em plantas e microorganismos. Viçosa, MG: UFV, 1998. 574p.

BERJAK, C. Unifying perspectives of some mechanisms basic to desiccation tolerance across life forms. Seed Science Research, v.16, p.1-15, 2006.

BLACKMAN, S.A.; WETTLAUFER, S.H.; OBENDORF, R.L.; LEOPOLD, A.C. Maturation proteins associated with desiccation tolerance in soybean. Plant Physiology, v.96, p.868-874, 1991.

BRANDÃO JR, D.S.; VIEIRA, M.G.G.C.; HILHORST, H.W.M. Aquisição da tolerância à dessecação nos diferentes estádios de desenvolvimento de sementes de cafeeiro (Coffea arabica L.). Ciência e Agrotecnologia, v.26, n.4, p.673-681, 2002. http://www.scielo.br/scielo.php?pid=S0101$31222002000200004 \&$ script $=$ sci_arttext

BRASIL. Ministério da Agricultura, Pecuária e Abastecimento. Regras para análise de sementes. Ministério da Agricultura, Pecuária e Abastecimento. Secretaria de Defesa Agropecuária. Brasília: MAPA/ACS, 2009. 395p. http:// www.bs.cca.ufsc.br/publicacoes/regras\%20analise\%20sementes.pdf

DOWNIE, B.; HILHORST, H.W.M.; BEWLEY, J.D. A new assay for quantifying endo- $\beta$-mananase activity using Congo Red dye. Phytochemistry, v.36, p.829-835, 1994.

ELLIS, R.H.; HONG, T.D.; ROBERTS, E.H. An intermediate category of seed storage behaviour?: II. Effects of provenance. Journal of Experimental Botany, v.42, n.238, p.653-657, 1991.

FAGAGNA, F. D. Living on a break: cellular senescence as a DNA-damage response. Nature Reviews, v.8, n.1, p.512-522,2008. http://www.nature.com/ $\mathrm{nrc} / \mathrm{journal} / \mathrm{v} 8 / \mathrm{n} 7 / \mathrm{abs} / \mathrm{nrc} 2440 . \mathrm{html}$

GUIMARÃES, R.M. ; VIEIRA, M.G.G.C. ; FRAGA, A.C. ; PINHO, E.V.R.V.; FERRAZ, V.P. Tolerância à dessecação em sementes de cafeeiro (Coffea arabica L.). Ciência e Agrotecnologia, v.26, p.128-139, 2002. http://www. scielo.br/scielo.php?pid=S0101-31222002000200004\&script=sci_arttext

LEPRINCE, O.; HENDRY G.A.F.; MCKERSIE, B.D. The mechanisms of desiccation tolerance in developing seeds. Seed Science Research, v.3, n.3, p.231-246, 1993. http://journals.cambridge.org/action/ displayAbstract;jsessionid=DCE6FB89E1106B3487C2C8E4CCE04542. journals? fromPage $=$ online $\&$ aid $=1353464$

MARCOS- FILHO, J. Fisiologia de sementes de plantas cultivadas. Piracicaba: FEALQ, 2005. 496p.

MARRACCINI, P.; ROGERS, W.J.; ALLARD, C.; ANDRÉ, M. L.; CAILlET, V.; LACOSTE, N.; LAUSANNE, F.; MICHAUX, N. Molecular and Biochemical characterization of endo- $\beta$-mannanases from germinating coffee (Coffea arabica) grains. Planta, v.214, p.296-308. 2001.

PEREIRA, L.F.P.; GALVÃO, R.M.; KOBAYASHI, A.K. Produção de etileno e expressão do gene de ACC-oxidase durante a maturação de frutos de Coffea 
arabica L. Brazilian Journal Plant Physiology, v.17, n.3, p.283-289, 2005.

PEZZOPANE, C.G.; MEDINAFILHO, H.P.; BORDIGNON, R.; SIQUEIRA, W.J.; AMBRÓSIO, L.A.; MAZZAFERA, P. Influências Ambientais no Rendimento Intrínseco do Café. Bragantia, v.64, n.1, p.39-50, 2005. http:// www.redalyc.org/pdf/908/90864105.pdf

PEZZOPANE, J.R.M.; PEDRO JÚNIOR, M.J.; THOMAZIELLO, R.A.; CAMARGO, M.B.P. Escala para avaliação de estádios fenológicos do cafeeiro Arábica. Bragantia, v.62, n.3, p.499-505, 2003. http://www.scielo. br/scielo.php?script=sci_arttex\&pid=S0006-87052003000300015

ROSA, S.D.V.F.; VON PINHO, E.V.R.; VIEIRA, E.S.N.; VEIGA, R.D.; VEIGA, A.D. Enzimas removedoras de radicais livres e proteínas lea associadas à tolerância de sementes milho à alta temperatura de secagem. Revista Brasileira de Sementes, v.27, n.2, p.91-101, 2005. http://www.scielo. $\mathrm{br} / \mathrm{sciel}$.php?script=sci arttext\&pid=S0101-31222005000200014

ROSA, S.D.V.F.; CARVALHO, A.M.; McDONALD, M.B.; VON PINHO, E.R.V.; SILVA, A.P.; VEIGA, A.D. The effect of storage conditions on coffee seed and seedling quality. Seed Science and Technology, v.39, p.151-164. 2011. http:// www.ingentaconnect.com/content/ista/sst/2011/00000039/00000001/art00013

ROSA, S.D.V.F.; MELO, L.Q; VEIGA, A.D.; OLIVEIRA, S.; SOUZA, C.A.S.; AGUIAR, V.A. Formação de mudas de Coffea arabica L., cv Rubi, utilizando sementes ou frutos em diferentes estádios de desenvolvimento. Ciência e Agrotecnologia, v.31, n.2, p.349-356. 2007. http://www.scielo.br/ scielo.php?pid=S1413-70542007000200013\&script=sci_arttext

ROSA, S.D.V.F.; VON PINHO, E.V.R.; CARVALHO, M.G.; VEIGA, R.D. Eficácia do teste de condutividade elétrica para o uso em estudos de danos de secagem em sementes de milho. Revista Brasileira de Sementes, v.22, n.1, p.54-63, 2000.

SILVA, E.A.A; TOOROP, P.E; AELST, A.C.V.; HILHORST, H.W.M. ABA regulates embryo growth potential and endosperm cap weakening during coffee (Coffea arabica cv. Rubi) seed germination. Planta, v.220, n.2, p.251261, 2004. http://link.springer.com/article/10.1007\%2Fs00425-004-1344-0

TAIZ, L.; ZEIGER, E. Fisiologia vegetal. Porto Alegre: Artmed, 2004. p.449-484.

TAKAHASHI, A.; OHTANI, N.; HARA, E. Irreversibility of cellular senescence: dual roles of $16^{\mathrm{INK} 4 \mathrm{a}} / \mathrm{Rb}$-pathway in cell cycle control. Cell Division, v.2, n.10, p.1-5, 2007. http://www.celldiv.com/content/2/1/10

VEIGA, A.D.; GUIMARÃES, R.M.; ROSA, S.D.V.F.; VON PINHO, E.V.R.; SILVA, L.H.C.; VEIGA, A.D. Armazenabilidade de sementes de cafeeiro em diferentes estádios de maturação e submetidas a diferentes métodos de secagem. Revista Brasileira de Sementes, v.29, n.1, p.83-91, 2007. http://www.scielo.br/ scielo.php?script=sci_arttext\&pid=S0101-31222007000100012

VIEIRA, A.R.; OLIVEIRA, J.A.; GUIMARÃES, R.M.; PEREIRA, C.E.; CARVALHO, F.E. Armazenamento de sementes de cafeeiro: ambientes e métodos de secagem. Revista Brasileira de Sementes, v.29, n.1, p.76-82, 2007. http://www.scielo.br/scielo.php?pid=S0101-31222007000100011\&script=sci_ abstract\&tlng=pt

WOLKERS, W.F.; BOCHICCHIO, A.; SELVAGGI, G.; HOEKSTRA, F.A. Fourier transform infrared microscopy detects changes in protein secondary structure associated with desiccation tolerance in developing maize embryos. Plant Physiology, v.116, n.3, p.1169-1177, 1998. http://www.ncbi. nlm.nih.gov/pmc/articles/PMC35087/ 